\title{
Corporate governance, financing and gender: A study of SMEs from Argentinean Securities Markets
}

\author{
Gobierno corporativo, financiamiento y género: un estudio de las pymes \\ emisoras de títulos en los mercados de valores argentinos \\ Anahí Briozzo $^{\mathrm{a}, *}$, Diana Albanese ${ }^{\mathrm{b}}$, Diego Santolíquido ${ }^{\mathrm{b}}$ \\ a Departamento de Ciencias de la Administración, Universidad Nacional del Sur (UNS)-CONICET, \\ Bahía Blanca, Argentina \\ b Departamento de Ciencias de la Administración, Universidad Nacional del Sur (UNS), Bahía Blanca, Argentina
}

Received 27 November 2014; accepted 30 June 2016

Available online 23 March 2017

\begin{abstract}
The objective of this work is to study corporate governance (CG) and the financing of small and medium sized enterprises (SMEs) from a gender perspective. Particularly, the participation of women in the holding, administration (board of directors and senior management), and external audit of the SMEs that participate in the Argentinian stock markets is analyzed. The results show that there are significant relations between the participation of women in ownership, external audits, and financing decisions. However, no relation is found between the participation of women at the different levels of the CG.

(C) 2014 Universidad Nacional Autónoma de México, Facultad de Contaduría y Administración. This is an open access article under the CC BY-NC-ND license (http://creativecommons.org/licenses/by-nc-nd/4.0/).
\end{abstract}

JEL classification: G34; G32; J16; M42

Keywords: Corporate governance; Gender; Small and medium sized enterprises; Financing

\section{Resumen}

El objetivo de este trabajo es estudiar el gobierno corporativo y el financiamiento en pequeñas y medianas empresas desde una perspectiva de género. En particular, se analiza la participación de mujeres en la propiedad, administración (directorio y alta gerencia) y auditoría externa en las pequeñas y medianas empresas que participan de los mercados de valores argentinos. Los resultados muestran que existen relaciones

\footnotetext{
* Corresponding author.

E-mail address: abriozzo@uns.edu.ar (A. Briozzo).

Peer review under the responsibility of Universidad Nacional Autónoma de México.
} 
significativas entre la participación de mujeres en la propiedad y la auditoría externa, y las decisiones de financiamiento. Sin embargo, no se encuentra relación entre la participación de mujeres en los distintos niveles del gobierno corporativo.

(C) 2014 Universidad Nacional Autónoma de México, Facultad de Contaduría y Administración. Este es un artículo Open Access bajo la licencia CC BY-NC-ND (http://creativecommons.org/licenses/by-nc-nd/4.0/).

Códigos JEL: G34; G32; J16; M42

Palabras clave: Gobierno corporativo; Género; Pequeñas y medianas empresas; Financiamiento

\section{Introduction}

According to the data of the World Bank, ${ }^{1}$ in Latin America and the Caribbean $40.2 \%$ of companies have at least one woman as owner, and $21.1 \%$ of the firms are directed by a woman. In Argentina, the participation of women in ownership is of $38 \%$, while the female role in general management is lower than the average of the region, at around 9.2\%. The relevance of the participation of women in the ownership and direction of enterprises, along with the differential characteristics of the small and medium sized enterprises (SMEs), has promoted a branch of studies regarding this sector to be addressed in matters of gender. This work is placed in the framework of studies on the financing and gender of SMEs, considering the role of women in the ownership and management of the enterprise, all the while adding a new aspect to the problem: the role of the other corporate governance (CG) mechanisms such as the directory and the external auditor.

The development of the CG mechanisms is especially relevant in companies that look for longterm funds in capital markets, a financing segment where the presence of the SMEs is still scarce. According to the Instituto Argentino de Mercados de Capitales (2013), in Argentina, long-term financing (negotiable obligations and financial trusts) destined to SMEs through the domestic capital market in 2013 was $14.6 \%$ of the funds obtained by the SMEs sector, and $0.9 \%$ of the total business financing. In order to incentivize the participation of the SMEs in the capital markets, Argentina has developed special regimes that facilitate the processes and decrease the issuance costs of bonds for companies (Res. Gral. Comisión Nacional de Valores - CNV - No. 336/99, CNV Standards, 2013). Particularly, regarding the aspects of the CG, the SMEs are exempt from having a collegiate supervisory body and an Audit committee, and they are not required to present the Code of Corporate Governance. This means that the information on the CG of these companies is disseminated on the different public access documents that the companies present to the CNV, such as statements, information from relevant events, and issuance prospects, among others.

According to this information, the objective of this work is to study the corporate governance and financing in SMEs from a gender perspective. The work is addressed from a descriptivecorrelational point of view, with the SMEs that issue negotiable obligations in the Argentinian stock market as the study population. The results show that there is a relation between the financing of companies and the participation of women in ownership and external audits. However, no relation is found between the different mechanisms of CG and women's participation in the same.

The contributions of this work lie in the following bases: (i) the relation between corporate governance, gender, and financing is studied from a broad point of view regarding the mechanisms

${ }^{1}$ Banco Mundial (2010). 
of the CG, considering ownership, board of directors, senior management and external auditor; (ii) the SMEs of a developing country are studied, when the majority of the previous works have been based on developed countries; and (iii) a single database comprised by non-standardized public access information is analyzed.

The work is structured in the following manner: first, the theoretical framework and the empirical background are presented; second, the methodology is detailed; third, the results are analyzed; and finally, the conclusions are presented.

\section{Theoretical framework and empirical background}

This section presents the conceptual framework and the previous studies. First, regarding the CG and SMEs in general; second, regarding the CG and the participation of women; finally, the relation between gender and financing is addressed. Each one of these sub-sections is accompanied by the presentation of the hypotheses. Lastly, the temporary and geographical context of the participation of women in the management and ownership of companies is described.

\section{Corporate governance in SMEs}

Corporate governance can be defined as the "set of principles, policies, procedures, standards, and norms that are used to direct and control an entity of any nature, size or condition, in an ethical, equitable, and responsible manner. This set regulates the design, integration and functioning of the government bodies, reflecting the power relations between shareholders, directories and senior management." (Casal, 2010, p. 1)

The classic conceptual framework for corporate governance departs from the agency theory (Jensen \& Meckling, 1976). In a context of large open capital companies with atomized property, conflicts arise between shareholders and management derived from the separation of property and control (principal-agent problem). However, in developing countries, the concentration of the property, in addition to weaker governance mechanisms, results in conflicts between majority and minority shareholders. This is known as principal-principal conflict (Young, Peng, Ahlstrom, Bruton, \& Jiang, 2008). The principal-principal conflict derives from the extraction of richness from the minority shareholders by the majority shareholders through the assignment of unqualified personnel to key positions (friends and/or family), the acquisition of services or products at overvalued prices, or the sale of products at undercut prices to entities controlled by the same group of shareholders, and the development of strategies that favor personal, family or political interests.

Good CG practices would act through the mitigation of information asymmetries, thus reducing agency costs, which would translate into a better performance of the company. Different works find evidence in favor of this relation. For large companies in emerging markets, see Campos, Newell, and Wilson (2002), Klapper and Love (2004), Garay and González (2008), Braga Alves and Shastri (2011), among others.

The empirical literature on CG in SMEs has been expounded upon mainly in developed markets. Abor and Adjasi (2007) indicate that the CG mechanisms in SMEs that receive the most attention are:

- Separation of senior management from the board of directors, in order to ensure the position of control that the board of directors has on management. This includes preventing the duality of the CEO. 
- An adequate mix of independent and internal directors.

- Independence of the external auditor to ensure the integrity of the financial reports.

It is interesting to mention that, even if the mechanisms of the CG could be, in principle, similar to those of large companies, the empirical evidence in SMEs is not homogenous. For example, Arosa, Iturralde, and Maseda (2013) report that the size of the board of directors and the percentage of external directors negatively affect the performance of Spanish SMEs. These results would indicate the effects of the lack of coordination, flexibility, and communication in a large board of directors.

Brunninge, Nordqvist, and Wiklund (2007) found that in the Swedish SMEs with the highest concentration of ownership there is a lower tendency toward strategic change, which would be associated with risk aversion and resistance to change. The presence of external directors and the number of members in senior management have a positive effect on strategic changes, and these two mechanisms act, to some extent, as surrogates to one another.

Dasilas and Papasyriopoulos (2015) study SMEs and large Greek companies with open capitals, and find that the size of the board of directors has a negative effect on the short-term debt, even if this relation is weaker for smaller companies. This result would be explained by the higher participation of shareholders in the board of directors of smaller companies, which would decrease information asymmetries (from a principal-agent problem approach).

For Argentina, Santolíquido, Briozzo, and Albanese (2014) study the relation between CG, age and formation of the different organizational levels, and the financing and performance of the companies. The size of the board of directors negatively affects the period of indebtedness. It can be observed that there is a negative relation with the ratio of Total Liabilities to Sales for the age variable of the president of the board of directors, as well as the average age of the members of the board. A board of directors with a higher academic formation tends to acquire long-term debts, and is also associated with a better performance. Regarding the duality of the CEO, in $50 \%$ of the companies where the president of the board of directors has a degree in economic sciences, it is also the General Manager; while this percentage decreases to $10 \%$ for companies with a president of the board of directors without said training.

\section{Gender and corporate governance}

Among the $\mathrm{CG}$ mechanisms that emerge to prevent the agents from manipulating the accounting results using different principles and accounting methods, we found the figures of the directors and the external auditors. We are interested in analyzing the current situation of these mechanisms from a gender perspective, that is, evaluating the role of women in the same.

Interest on this subject can be traced back to Daily, Certo, and Dalton (1999), who analyze how female participation progressed in the main management and directive positions in the 1990s. A series of investigations derive from this analysis that study the topic from different points of view and with different objectives. Francoeur, Labelle, and Sinclair-Desgagné (2008) attempt to determine how the performance of the firm is affected by having women in the board of directors and in the first line management from the perspective of the stakeholders ${ }^{2}$ (interested parties).

\footnotetext{
${ }^{2}$ Interested parties are those people and institutions that have any type of relation with the company (employees, government, suppliers, proprietors, creditors, general public, etc.). According to this perspective, the inclusion of women in management positions comes about due to the pressure exerted by these groups.
} 
They find that the firms in which women have management positions have a better performance, but that having more women in the board of directors does not ensure a higher market value. Consistently, Farrell and Hersch (2005) do not find a positive relation between the generic diversity of the Board of Directors and the market value, which leads them to conclude that the inclusion of women in directive positions is due to other factors (external pressure, image improvement, company objectives, etc.).

In order to know how to improve the performance of the firm through the inclusion of a higher percentage of women in the board of directors, it is important to consider how the investors respond to this phenomenon. In this sense, Kang, Ding, and Charoenwong (2010) prove that, in the case of Singapore, they answer positively to the addition of women to the board of directors, and attribute the results to different reasons: that the community of this country has a positive outlook on women having a high status in society and having an important role in the decision making process, that leading businessmen profess the benefits of diversified groups, and that the latter has its disadvantages (the time necessary for the making of decisions and reaching consensus increases), but that this mainly occurs in highly diverse groups (this is not the case of Singapore).

López Vergara, Gómez-Betancourt, and Betancourt Ramírez (2011) study the factors that influence the participation of women in CG bodies in family companies in Colombia, and conclude that these are relevant motives for heritage conservation, professional growth, and the preservation of the family unit, the contribution to the development of the firm, and the generation of family communication spaces.

Similarly, it should be considered how this inclusion happens, which may due to different sources: external pressure, explicit company policies, and to improve the company image (Farrell $\&$ Hersch, 2005). These authors aim to explain the motive that may cause the incorporation of a woman to the board of directors, taking into consideration whether it is as a replacement when one of the members retires, and whether the person retiring is a man or a woman, in addition to attempting to model the probability of incorporating a woman as a replacement for a member or by increasing the number of people in the board of directors. The results of their analysis show that the probability of including a woman in the board of directors in a certain year is negatively related to the percentage of existing women in the same board in the previous year. They conclude that the gender influences the selection of the board of directors. According to the expected positive relation regarding female participation in the different bodies of $\mathrm{CG}$, the following hypotheses are formulated:

Hypothesis 1. There is a positive relation between the participation of women in ownership and female participation in the board of directors.

Hypothesis 2. There is a positive relation between the participation of women in ownership and female participation in senior management.

Hypothesis 3. There is a positive relation between the participation of women in the board of directors and female participation in senior management.

Other studies focus on how gender affects the other CG mechanism: external audit (Ittonen, Vähämaa, \& Vähämaa, 2013; O'Donnell \& Johnson, 2001). The same start from the selectivity hypothesis, ${ }^{3}$ and attempt to determine whether women and men auditors show differences based

\footnotetext{
${ }^{3}$ It indicates that men and women follow different strategies for the processing of information; men are prone to following simpler processes, whereas women follow more complex processes.
} 
on gender regarding the resolution of different problems, proving that women perform better when it comes to complex problems (they take less time to solve them than men); however, men are more efficient when it comes to simple tasks. The results do not imply that one gender makes better decisions than the other, but that they focus their performance regarding time and complexity. According to the expected positive relation regarding female participation in the different bodies of the CG, the following hypotheses are formulated:

Hypothesis 4. There is a positive relation between the participation of women in ownership and the existence of a woman as an external auditor.

Hypothesis 5. There is a positive relation between the participation of women in the board of directors and the existence of a woman as an external auditor.

Hypothesis 6. There is a positive relation between the participation of women in senior management and the existence of a woman as an external auditor.

\section{Gender and SMEs financing}

The study on the impact of gender on the financing decisions of the SMEs has traditionally focused on the role of the owner-administrator. Following Constantinidis, Cornet, and Asandei (2006), in this gender-financing relation, some factors associated with the demand of funds (the behavior of businesswomen vs. businessmen in financing decisions) and with the offer (the behavior of fund suppliers before businesswomen vs. businessmen) can be identified.

Regarding demand arguments, differential characteristics emerge in terms of women as decision makers (social vision of feminism), for example, a greater aversion to risk. In relation to this, women and men differ regarding the type of motivations to start a company, their abilities with business, the level of confidence in themselves, and their priorities in management tasks (Johnsen \& McMahon, 2005). Therefore, the differences in financing that exist in companies led by men and women would respond, in part, to the differences in the characteristics of the companies they lead, particularly regarding the sector, size, age, and structure of the property (Constantinidis et al., 2006). Women generally begin small business, in traditional sectors with low growth (mainly services and minority commerce), with single-owner structures. This would explain the lower amount of capital invested, and the fact that they are less attractive ventures for fund providers.

Regarding offer arguments, it is indicated that in terms of conditions equality, women suffer more obstacles than men when looking for external financing (liberal feminist view). The predictions of both approaches (demand and offer) are similar in terms of the results observed, that is, a reduced use of external financing by businesswomen. Carter, Shaw, Lam, and Wilson (2007, p. 428) indicate that "the evidence, considering gender, entrepreneurship, and bank credit, suggests that the financing profiles are distinctively different, which is attributable in great part (but not fully) to structural differences".

Regarding the offer and demand arguments in terms of the role of the owner-administrator, the following hypotheses are formulated:

Hypothesis 7. Female participation in ownership is associated with a reduced indebtedness at a shorter term.

Hypothesis 8. Female participation in senior management is associated with a reduced indebtedness at a shorter term. 
Regarding the role of other CG mechanisms in indebtedness, Mínguez-Vera and LópezMartínez (2010) analyze this phenomenon in Spanish SMEs, and find that female representation in the board of directors generates a positive effect in the performance of the company (the positive effects of gender diversification exceed the negative). They confirm the assumption that women in the board of directors, being more averse to risk than men, are prone to work in companies with a lower debt ratio and bankruptcy probability. Based on this, the following hypothesis is formulated:

Hypothesis 9. Female participation in the board of directors is associated with a reduced indebtedness at a shorter term.

Lastly, Ittonen et al. (2013) confirm that the differences regarding aversion to risk, diligence, and conservatism between genders have an influence on the quality of the accounting reports, since female auditors are more precise and efficient in their production. This implies a greater security in the financial report, which could be associated to a higher confidence for undertaking a debt. Thus, it is expected that companies with financial statements audited by women are handled with higher levels of debts, and at a longer term. As such, the following hypothesis is formulated:

Hypothesis 10. The firms audited by women undertake more debt and at a longer term than those audited by men.

\section{Temporal and geographical context}

According to data from Grant Thornton International, ${ }^{4}$ the participation of women in directive positions in Argentina is below the world average (19.4\% vs. 22.2\% for the period of 2011-2015). As presented in Figure 1, the participation of women in management positions in private and public companies in Argentina was of $16 \%$ for 2015, which is consistent with 2007, year in which the measurement began. Increases in the percentages of participation were present during the period between the years mentioned, only to decrease in the last year analyzed. A similar analysis can be done regarding the world average of female employment in managerial positions. Regarding other Latin American countries, it is found that the tendency is consistent with the monthly average of Mexico, even though the participative percentage is superior to Argentina. A relevant factor is the significant decrease of the participation of women in Brazil, which in 2007 was of $42 \%$, being one point below Argentina in 2015.

Some of the motives that would explain the low female participation are related to the economic slowdown of the countries in question, and to the difficulties for women with children, not only regarding the cost of childcare, but also the complex matter of family planning. In Argentina, the managerial positions filled by women are general managers, human resources directors and, to a lesser extent, company presidents or vice-presidents.

In the reports of Grant Thornton International, an increasing support manifests for the establishment of quotas, so that a greater number of women comprise the governing boards. The greatest impulse is shown by the European Union.

The World Bank also generates information regarding female participation in ownership and high managerial positions through its World Enterprise Surveys, which includes companies with

\footnotetext{
${ }^{4}$ Company that provides audit, consultancy, and advice services to private and public companies, Grant Thornton Argentina - as each of the member and correspondent firms - stands as an autonomous firm. The aforementioned firm issues the International Business Report (IBR) elaborated through surveys to public and private companies. The data emerge from interviews to more than 5 thousand executive directors, general directors, presidents, and senior executives.
} 


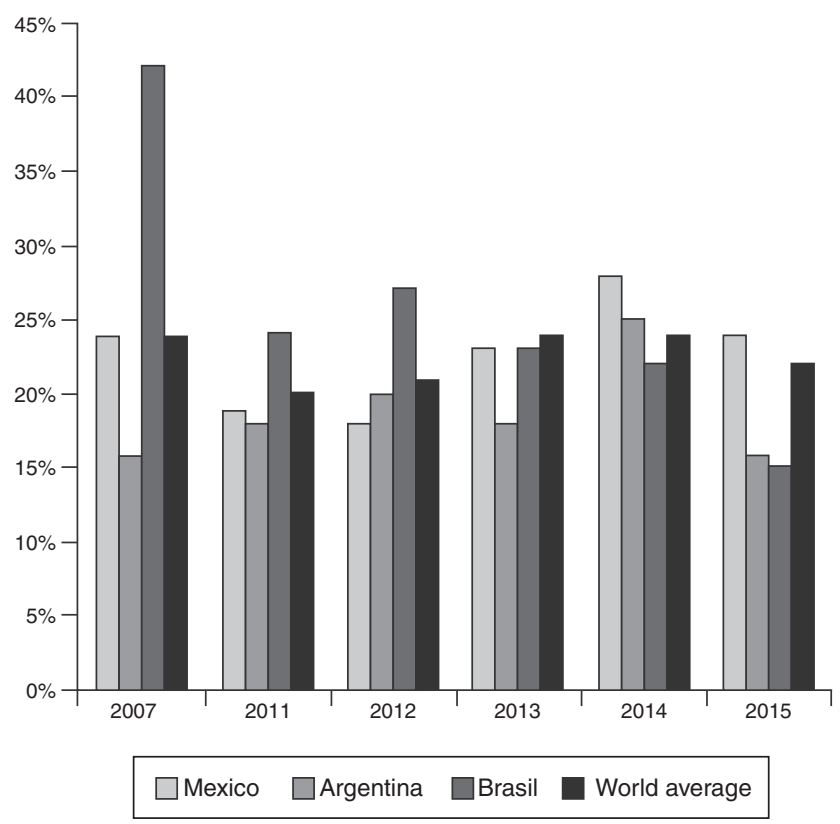

Figure 1. Evolution of the participation of women in managerial positions. Source: Grant Thornton International.

more than five employees. Table 1 shows that in Argentina, the participation of women in ownership is on average similar to the rest of Latin America, but when discriminating by the size of the company said participation decreases more clearly than for the rest of the countries, especially in the case of larger companies. Similarly, by analyzing female participation as a main directive of the company, the average is notably below that of the rest of the countries. In this aspect, women participation decreases with the size of the company in all the countries, but it is more pronounced for the case of Argentina.

Concerning the norms on female participation, there are no laws in Argentina that regulate the participation of women in the board of directors of companies. In terms of politics, the National

Table 1

Female participation in the ownership of a business and in the main managerial position, by company size.

\begin{tabular}{llll}
\hline & Argentina & Latin America and the Caribbean & Globally \\
\hline $\begin{array}{l}\text { Percentage of companies with women } \\
\quad \text { participation in the ownership }\end{array}$ & $38 \%$ & $39.80 \%$ & $33.90 \%$ \\
Small (5-19 employees) & $46.90 \%$ & $41.20 \%$ & $33.70 \%$ \\
Medium (20-99 employees) & $30.40 \%$ & $39.50 \%$ & $33.90 \%$ \\
Large (more than 100 employees) & $16.30 \%$ & $31.50 \%$ & $36.80 \%$ \\
Percentage of companies with women in & $9.20 \%$ & $21.10 \%$ & $17.30 \%$ \\
$\quad$ their senior management & $11.90 \%$ & $23.70 \%$ & $19.60 \%$ \\
Small (5-19 employees) & $6.90 \%$ & $20 \%$ & $14.30 \%$ \\
Medium (20-99 employees) & $3.60 \%$ & $10.60 \%$ & $10.20 \%$ \\
Large (more than 100 employees) & & & \\
\hline
\end{tabular}

Source: Banco Mundial (2010). 
Law 24.012 governs since 1991. This law is also known as the female quota law, which requires party lists to fill national elective positions to be comprised of at least $30 \%$ women. This has been an important step not only for the development of women, but also from a social point of view, to address gender equality, the defense of women and children rights, among others. Despite the successful participation of women since the female quota law, this same law has not guaranteed profound transformations regarding gender equality.

\section{Methodology}

This section presents the methodological details of the work. First, the population under study and the data sources will be defined. The statistical tools used in the analysis and the definitions of the variables are described below.

Data

The universe studied is comprised by the SMEs that issue marketable securities from January 2011 to April 2014 in the Argentinian stock market. Only those companies registered as stock corporations are taken into consideration. The definition of SME corresponds to the General Resolution 582/10 of the National Securities Commission (CNV) (emissions 2011-2012) and Resolution 50/13 of the Secretariat for Small and Medium-sized Enterprises and Regional Development (Secretaría de la Pequeña y Mediana Empresa y Desarrollo Regional) (emissions 2013 and 2014). ${ }^{5}$

The population is a total of 33 SMEs, three of which are equity issuers and the rest have only issued corporate bonds. The complete listing of companies is presented in the Annex, Table 7. The database of Santolíquido et al. (2014), where they study CG and financing and performance variables, evaluated differentially according to the age and education of the different organizational levels. Unlike said work, the objective of this article is to analyze CG and financing from a gender perspective.

According to the Ministry of Industry of the Republic of Argentina, there are 603,000 SMEs in the country. The 33 companies that comprise the population of study, which are SMEs that do public offerings of their debt and/or capital securities, are a very small fraction of these companies. However, they are a group of great interest due to being companies that have entered the capital market and comprise a financing segment that the national public policies have looked to develop and promote for the SMEs. Similarly, as they are companies under the public offering regime, information about them is available freely to the public.

Under the Argentinian regulation, SMEs are exempt from having a collegiate supervisory body and an Audit Committee, and they are not required to present the Code of Corporate Governance. This means that the information on the CG of these companies is disseminated on the different public access documents presented by the companies to the $\mathrm{CNV}$, such as statements, information from relevant events, and issuance prospects, among others. ${ }^{6}$ Therefore, it was necessary to collect and systemize all this dispersed information into a single database in order to carry out this study. The CG variables correspond to the issuance prospects, while the financial data are measured

\footnotetext{
5 See Annex: Table 6, for more details on how to determine the condition of the SME.

${ }^{6}$ Information available in the Financial Information Section of the CNV, http://www.cnv.gob.ar/info_ Financiera.asp?Lang=0.
} 
at the time of issuance and the end of the fiscal year. Taking into consideration the complete information for all the companies, the sample comprises a total of 22 firms.

\section{Statistical tools}

The study carried out was quantitative and of a descriptive-correlational character. For the analysis of relations between variables the following methods are used:

- Bivariate analysis with a quantitative dependent variable: Given the reduced size of the population under study, the normality of the data cannot be assumed. Therefore, Spearman's rank correlation is used for quantitative variables (for example, percentage of women stockholders and percentage of women in senior management), and the Mann-Whitney and the Kruskal-Wallis tests are used to analyze a quantitative variable against a categorical one (for example, percentage of women in the board of directors and female auditors).

Spearman's correlation coefficient (rho) is a measure of the linear association between two random continuous variables. The ranges and number of orders of each group of subjects are analyzed, and said ranges are compared. The value of rho oscillates between -1 (perfect negative association) and +1 (perfect positive association), and is calculated as follows:

$$
r h o=1-\frac{6 \sum d_{i}^{2}}{N\left(N^{2}-1\right)}
$$

where

$d_{i}=$ difference between the ranges $\left(x_{i}\right.$ minus $\left.y_{i}\right)$

$N=$ number of observations.

The Mann-Whitney $U$ test is a non-parametric method that tests the differences in a continuous variable against a nominal variable when it has two categories. The null hypothesis is that the medians of the populations from which the two samples come from are equal. The $U$ test is calculated as follows:

$$
U=n_{1} n_{2}+\frac{n_{2}\left(n_{2}+1\right)}{2}-\sum_{i=n_{1}+1}^{n_{2}} R_{i}
$$

where

- $n_{1}=$ size of sample 1

- $n_{2}=$ size of sample 2

- $R_{i}=$ range of sample $i$

The Kruskal-Wallis test assesses the differences in a continuous variable against one nominal variable when it has three or more categories. It is a non-parametric test, as it does not require the premise of normality. It entails arranging all the observations of the sample from larger to smaller, and assigning the ranges consecutively. Subsequently, the ranges assigned to each observation are added, grouping them into sets for each of the study groups and then comparing the sums obtained in each of the groups through a statistical comparison, and evaluating their value with respect to the Chi square distribution law with $k-1$ degree of liberty, where $\mathrm{k}$ 
indicates the number of groups being compared. The Kruskal-Wallis $(H)$ statistic is calculated as follows:

$$
H=\frac{12}{N(N+1)} \sum_{i=1}^{k} \frac{R_{i}^{2}}{n_{i}}-3(N+1)
$$

where

- $n_{i}(i=1,2, \ldots, k)=$ the size of each of the samples for the $k$ groups of the data. Each one of the $n_{i}$ should be at least 5 for the test to be valid.

- $R_{i}=$ the sum of the ranges of group $i$.

- $N=$ total number of observations in all the samples.

- Bivariate analysis with a categorical dependent variable: to test the independence between two categorical variables, the Pearson $\mathrm{Chi}^{2}$ and Fisher's exact tests are applied. Two categorical variables (such as a woman as main shareholder and a female auditor) are considered independent if all the joint probabilities are equal to the product of the marginal probabilities. In this case, the null hypothesis would be, for example, that the percentage of female auditors is equal when the main shareholder is a man or when it is a woman, which is rejected if the p-value is inferior to the critical level (for example, $5 \%$ ).

The Pearson $\mathrm{Chi}^{2}$ test is calculated as follows:

$$
\chi^{2}=\sum_{i=1}^{n} \frac{\left(O_{i}-E_{i}\right)^{2}}{E_{i}}=N \sum_{i=1}^{n} p_{i}\left(\frac{\left(O_{i} / N\right)-p_{i}}{p_{i}}\right)^{2}
$$

where

- $\chi^{2}=$ statistical value

- $O_{i}=$ number of observations of the " $i$ " type

- $N=$ total of observations

- $E_{i}=N p_{i}=$ the expected frequency of the " $i$ " type, derived from the null hypothesis that states the $i$ fraction in the population is $p_{i}$

- $n=$ number of cells in the table

Fisher's exact test is used when there is a cell in the contingencies table with $n<10$. Given two variables $X$ and $Y$, with $m$ and $n$ states observed respectively, a matrix is assembled with $m \times n$ dimensions, where the $a_{i j}$ represent the number of observations in which $x=i$ and $y=j$. The sum of the rows and columns is calculated, $R_{i}$ and $C_{j}$, respectively, and the total sum $N=\sum_{i} R_{i}=\sum_{j} C_{j}$. Subsequently, the conditional probability of obtaining the observed matrix given the particular sum of the rows and columns is calculated through:

$$
P=\frac{\left(R_{1} ! R_{2} ! \ldots R_{m} !\right)\left(C_{1} ! C_{2} ! \ldots C_{m n} !\right)}{N ! \prod_{i j} a_{i j} !}
$$

which is a multivariate generalization of the hypergeometric probability function.

Agrestri (2002) provides more information on these methods. 
The relations were also studied using multivariate analysis methods, but the global significance of the different regressions was low, ${ }^{7}$ due to the reduced sample size. In order to detect the possible presence of a spurious relation between $\mathrm{CG}$, gender and financing, the relation with a group of control variables was also analyzed, as detailed in the following section.

\section{Variables}

Table 2 presents the operative description of the variables used in the analysis. The statistical analysis of these variables was done in two stages:

- Analysis of CG and gender variables (percentage of female shareholders, shareholding in women, main shareholder is a woman, percentage of women in the board of directors, percentage of women in senior management, and female auditor) and financing variables (level of indebtedness and term).

- Analysis of the corporate governance and gender variables, and a group of control variables: sector, age, size (sales), whether it is a family company, participation of the main shareholder, and percentage of external directors. The relation between the different variables of the $\mathrm{CG}$ and gender was also tested to detect spurious relations in the previous stage.

\section{Results}

Firstly, Tables 3 and 4 present the characteristics of the population under study. The low participation of women in the ownership and administration of the company is highlighted, being the external audit the CG aspect with the most female participation. Ownership is strongly concentrated (median of 55\%), and the average size of the board of directors is of 3 people. Regarding the financing of companies, the use of short-term liabilities predominated. Only four companies have the participation of foreign capitals in their property.

Table 5 presents the results of the bivariate analysis. The results are presented in three blocks: in the first panel, the relations of the CG and gender variables are shown; in the second panel, the results of the CG, gender, and financing variables (term and source) are described; lastly, in the third panel, the relations of the of $\mathrm{CG}$ and gender variables and the control variables (age, sector, family company, size, percentage of external directors, and participation of the main shareholder) are presented.

- Property and gender: When analyzing the relation between these variables and financing (panel B), it has been found that those companies with a woman as a main shareholder tend to acquire more debt at a short term. Conversely, the percentage of female shareholders is negatively related to the term, whereas the concentration of shareholding in women is not related to financing.

As expected, the three ownership and gender variables are related among themselves (panel A). The percentage of female shareholders and shareholding in women presents a rho of 0.7 .

\footnotetext{
${ }^{7}$ Different econometric models were tested: ordinary least squares, generalized linear model, and quantile regression. In all cases a measure of the financing was combined as dependent variable, along with only two regressors due to the reduced sample size. The selection of regressors consisted in incorporating a corporate governance and gender variable and a control variable.
} 
Table 2

Operational definition of the variables.

\begin{tabular}{|c|c|}
\hline Variable & Definition \\
\hline \multicolumn{2}{|l|}{$C G$ and gender } \\
\hline Main shareholder is a woman & $\begin{array}{l}\text { It takes the value of " } 1 \text { " if the main shareholder of the firm } \\
\text { is a woman. Binary variable. }\end{array}$ \\
\hline Percentage of female shareholders & $\begin{array}{l}\text { Percentage of women that are shareholders on the total } \\
\text { of individual shareholders. Quantitative variable. }\end{array}$ \\
\hline Property in the hands of women & $\begin{array}{l}\text { Percentage of share capital in the hands of women. } \\
\text { Quantitative variable. }\end{array}$ \\
\hline Percentage of women in the board of directors & $\begin{array}{l}\text { Percentage that the total number of director women } \\
\text { represents in the board of directors. Quantitative variable. }\end{array}$ \\
\hline Percentage of women in senior management & $\begin{array}{l}\text { Percentage that the total number of manager women } \\
\text { represents in the senior management. Quantitative variable. }\end{array}$ \\
\hline The auditor is a woman & $\begin{array}{l}\text { It takes the value of " } 1 \text { " if the financial statements are } \\
\text { audited by a woman. It can be seen in the last closing } \\
\text { and in the closing presented in the prospect. Binary variable. }\end{array}$ \\
\hline \multicolumn{2}{|l|}{ Variables control } \\
\hline Family Company & $\begin{array}{l}\text { A company is considered a family company if the property } \\
\text { is fully or mostly comprised by people with the same last } \\
\text { name (or an explicitly established relation). Binary variable. }\end{array}$ \\
\hline External director & $\begin{array}{l}\text { An external director is that person who is neither the owner } \\
\text { nor an employee of the company. The proportion of external } \\
\text { directors is calculated in relation to the total. Quantitative } \\
\text { variable. }\end{array}$ \\
\hline Length of service in public offering & $\begin{array}{l}\text { Years since the publication of the first issuance prospect of } \\
\text { negotiable obligations until the publication of the issuance } \\
\text { prospect considered in this study. Quantitative variable. }\end{array}$ \\
\hline Age of the company & $\begin{array}{l}\text { Years since the first date of operations until the date of the } \\
\text { analyzed issuance prospect. Quantitative variable. }\end{array}$ \\
\hline Sales & $\begin{array}{l}\text { Sales of the period, measured for the closing of activities } \\
\text { on 2013. Quantitative variable. }\end{array}$ \\
\hline Service & $\begin{array}{l}\text { It takes the value of } 1 \text { if the company performs in an activity } \\
\text { sector within the area of services. Binary variable. }\end{array}$ \\
\hline \multicolumn{2}{|l|}{ Financing } \\
\hline Total Liabilities on the Net Worth & $\begin{array}{l}\text { Measured for the closing of activities on } 2013 \text { and for the } \\
\text { one presented in the issuance prospect. It measures the } \\
\text { financing ratio. Quantitative variable. }\end{array}$ \\
\hline Current Liabilities on Total Liabilities & $\begin{array}{l}\text { Measured for the closing of activities on } 2013 \text { and for the } \\
\text { one presented in the issuance prospect. It reflects the } \\
\text { short-term debt ratio on the total debt. Quantitative variable. }\end{array}$ \\
\hline Total Liabilities to Sales & $\begin{array}{l}\text { Measured for the closing of activities on } 2013 \text { and for the } \\
\text { one presented in the issuance prospect. It helps relativize } \\
\text { the liabilities of the company with a flow variable. } \\
\text { Quantitative variable. }\end{array}$ \\
\hline
\end{tabular}

Source: Own elaboration.

When the main shareholder is a woman, $51 \%$ of the shareholders are also women, against $23 \%$ when the main shareholder is a man. Meanwhile, shareholding in women is $53 \%$ when the main shareholder is a woman, against $6 \%$ when it is a man. However, the dissimilar results found regarding indebtedness would indicate that the different ways of measuring the participation of women in ownership are not perfect substitutes among themselves. 
Table 3

Descriptive statistics - quantitative variables.

\begin{tabular}{|c|c|c|c|c|}
\hline Variable & Median & Standard deviation & Min & Max \\
\hline \multicolumn{5}{|l|}{ Variables control } \\
\hline Age of the company (years) & 17.8 & 13.1 & 0.96 & 55.18 \\
\hline Number of employees (2013) & 129.9 & 190.4 & 8 & 871 \\
\hline Sales $(2013$, in millions of U\$) & 24.69 & 5.6 & 13.26 & 36.03 \\
\hline Length of Service in public offering (years) & 1.60 & 1.98 & 0.00 & 6.55 \\
\hline \multicolumn{5}{|l|}{ Variables of Corporate Governance } \\
\hline Number of shareholders ${ }^{\mathrm{a}}$ & 4.16 & 2.37 & 2.00 & 10.00 \\
\hline Percentage of female shareholders ${ }^{\mathrm{a}}$ & $27.77 \%$ & $30.83 \%$ & $0 \%$ & $100 \%$ \\
\hline Participation of the main shareholder ${ }^{\mathrm{a}}$ & $55.46 \%$ & $27.56 \%$ & $20 \%$ & $99 \%$ \\
\hline Property in the hands of women & $12.29 \%$ & $22.07 \%$ & $0 \%$ & $84.78 \%$ \\
\hline Number of people in senior management & 3.65 & 1.77 & 1.00 & 7.00 \\
\hline Percentage of women in senior management & $16.75 \%$ & $26.17 \%$ & $0 \%$ & $85.7 \%$ \\
\hline Number of members in the board of directors & 3.61 & 0.86 & 3.00 & 6.00 \\
\hline Percentage of women in the board of directors & $13.98 \%$ & $18.96 \%$ & $0 \%$ & $66.67 \%$ \\
\hline External directors (percentage) & $34.52 \%$ & $35.64 \%$ & $0 \%$ & $100 \%$ \\
\hline \multicolumn{5}{|l|}{ Financing } \\
\hline Current liabilities to Total liabilities (2013, CL/TL) & 0.81 & 0.19 & 0.33 & 1.00 \\
\hline Total liabilities to Net Worth (2013, TL/NW) & 4.27 & 7.11 & 0.84 & 40.45 \\
\hline Total liabilities to Sales $(2013, \mathrm{TL} / \mathrm{S})$ & 2.30 & 6.15 & 0.09 & 28.68 \\
\hline
\end{tabular}

Source: Own elaboration.

a Only for closely-held corporations. Note: Values in American dollars, converted in accordance with average of the Banco Nación retail dollar seller for 2013 (\$/U $\$=5.467)$.

Table 4

Descriptive statistics - categorical variables.

\begin{tabular}{llll}
\hline Control variables & $(\%)$ & CG variables & $\%$ \\
\hline Participation of the Services sector & $40.63 \%$ & Main female shareholder & 14.29 \\
Family company & 53.6 & Female auditor (2013) & 29.03 \\
\hline
\end{tabular}

Source: Own elaboration.

Note: The participation of the characteristic presented is indicated.

Regarding the analysis of control variables (panel C), it can be observed that shareholding in women has a positive relation with the size measured as sales $($ rho $=0.35)$. As the expected effect of the size of the company in the financing period is positive, due to the lesser asymmetries of information, this relation would, at best, reduce the negative effect observed in the main relationship of female shareholder and financing period, but it would not cause a spurious relation. Another interesting effect is that the participation of women in ownership implies a lower concentration of the same: there is a negative relation between the participation of the main shareholder and the shareholding in women $(\mathrm{rho}=-0.57)$ and if the main shareholder is a woman (concentration of 0.6 when the main shareholder is a man, and 0.25 when it is a woman).

Of the three ownership and gender variables that were studied, we considered the existence of a main female shareholder as the strongest indicator of the influence of women in the making of decisions. Shareholding in women and the percentage of female shareholders, though they are a measure of gender diversity in ownership, may be influenced by other aspects that also influence the making of decisions, such as shareholding. 
Table 5

Results of the bivariate analysis.

\section{Panel A - CG and gender}

Positive relation between percentage of female shareholders and the shareholding in women (rho $=0.7$, p-value $=0.0002$ ).

Positive relation between the main female shareholder and the percentage of female shareholders: when the main shareholder is a woman, $51 \%$ of the shareholders also are women, compared to $23 \%$ when the main shareholder is a man ( $p$-value $=0.06)$.

Positive relation between the main female shareholder and shareholding in women: shareholding in women is of 53\% when the main shareholder is a woman, compared to 6\% when the main shareholder is a man ( $p$-value $=0.001$ ).

There is no relation between percentage of female shareholders, percentage of women in the board of directors, and percentage of women in senior management. There is also no relation of these variables with the presence of a female auditor.

\section{Panel B - CG, gender and financing}

Property and gender

Positive relation between a female shareholder and short-term debt: ratio PC/PT $=91 \%$ when the main shareholder is a woman, $\mathrm{PC} / \mathrm{PT}=83 \%$ when the shareholder is a man $(p$-value $=0.045)$. There is no relation with the type of leverage.

The percentage of female shareholders is negatively related to the term of indebtedness $(\mathrm{rho}=-0.42$, $p$-value $=0.054)$. There is no relation with the type of indebtedness.

No significant relations are found for the shareholding in women/term/type of financing.

Administration and gender

The participation of women in the board of directors is not related to the financing variables.

The participation of women in senior management is not related to the financing variables.

Female auditor

Positive relation between a female auditor and the total indebtedness: PT/PN $=10.1$ when the auditor is a woman, and $\mathrm{PT} / \mathrm{PN}=2.54$ when the auditor is a man $(p$-value $=0.005)$. There is no relation with the remaining debt variables.

\section{Panel C - CG, gender and control variables}

Ownership and gender

Positive relation between shareholding in women and the size of the company measured as sales (rho $=0.35$, $p$-value $=0.064)$.

Negative relation between the participation of the main shareholder and the shareholding in women $(\mathrm{rho}=-0.57$, $p$-value $=0.001)$.

Negative relation between the shareholding of the main shareholder and if the main shareholder is a woman: average concentration of 0.6 when the main shareholder is a man, and 0.25 when it is a woman $(p$-value $=0.003)$. No significant differences were found for the variables of family company, age, sector, and external directors.

Administration and gender

The participation of women in the board of directors is higher in family companies $(22.7 \%$ vs. $4.1 \%$, $p$-value $=0.015$ ). No significant differences were found for the variables of age, sector, size, main shareholder participation, and external directors. The percentage of women in senior management is positively related to the percentage of external directors (rho $=0.4, p$-value $=0.073$ ). There is no relation to age, sector, size, main shareholder participation, and family company.

Auditor and gender

There is no relation between the presence of a female auditor and age, sector, size, family company, main shareholder participation, and external directors.

Source: Own elaboration.

Note: The aspects of ownership and gender are analyzed only for close-end companies.

Therefore, the results observed partially support the $\mathrm{H} 7$ hypothesis with regard to the relation between participation of women in ownership and the financing term.

- Administration and gender: The participation of women in the board of directors is not related to the financing variables (panel B), therefore there is no support for Hypothesis H9. Regarding 
the control variables (panel $\mathrm{C}$ ), there are no significant relations with the sector, age, size, participation of the main shareholder, nor with the participation of external sectors, though it is observed that in family companies the participation of women is higher in the board of directors. No significant relations are observed with the remaining variables of corporate governance and gender (panel A), so there is no evidence that supports H1 (relation between ownership and board of directors) nor $\mathrm{H} 3$ (relation between the board of directors and senior management).

Similarly, the percentage of women in senior management are also not related to the financing variables (panel B), therefore there is no evidence for H8. Regarding control variables, the percentage of women in senior management is positively related to the percentage of external directors $($ rho $=0.4)$, but there is no relation to the size, age, sector, family company, and participation of the main shareholder (panel C). Significant relations are also not observed with the rest of the corporate governance and gender variables (panel A), which leaves H2 without any evidence to support it (relation between ownership and senior management).

- Auditor and gender: The companies audited by women have a tendency for higher indebtedness with respect to the capital (panel B). The presence of a female auditor is not significantly related to the sector of the company, its size measured by sales, age, participation of the main shareholder or the percentage of external directors (panel C). Significant relations with the remaining variables of corporate governance and gender (panel A) are also not observed, which leaves hypotheses $\mathrm{H} 4$ (relation between ownership and a female auditor), H5 (relation between board of directors and a female auditor), and H6 (relation between board of directors and female auditor) without any support. When no relation was observed with the control variables, the correlation observed between the female auditor and financing does not result in a spurious relationship, therefore these results give partial support (regarding the type of financing) to hypothesis H10.

\section{Conclusions}

The mechanisms of corporate governance in the SMEs of emerging countries represent a scarcely studied subject, especially from a gender perspective. Regarding the results of this work, conclusions are established in different areas. Firstly, with regard to the relation between the CG and gender, it can be observed that there is no relation between the participation of women in different tiers: ownership, board of directors, senior management, and auditing. It is also interesting to observe that the concentration of capital decreases when more women participate in the ownership.

Conversely to what was indicated by Constantinidis et al. (2006), shareholding by women is related to a larger company size, a result that could be explained by the nature of the companies analyzed, which are participants in the capital market. It is also interesting to point out that the participation of women in senior management is positively related to the percentage of external directors, which is also consistent with Brunninge et al. (2007), regarding the role that external directors have in strategic change. Similarly, in family companies, the participation of women in the board of directors is higher, which can be explained by López Vergara et al. (2011): the motivation that arises from the conservation of heritage and the preservation of the family unit, among others. It is also worth highlighting that the characteristics of the CG and gender do not present significant differences regarding the sector and age of the company.

In line with Carter et al. (2007), differences can be observed in the financing profiles regarding the participation of women in the ownership of the company. When the main shareholder is a woman, there is a higher indebtedness at a short term. No relation is found between the participation 
Table 6

Definition of SME by the Secretariat for Small and Medium-sized Enterprises and Regional Development.

\begin{tabular}{llllr}
\hline \multicolumn{4}{c}{ Sector } \\
\hline Agriculture and Livestock & Industry and mining & Commerce & Services & Construction \\
\hline $6,382,978.72$ & $21,631,205.7$ & $29,550,827.4$ & $7,446,808.51$ & $9,929,078.01$ \\
\hline
\end{tabular}

Source: Own elaboration based on the table in Resolution 50/13 of the Secretariat for Small and Medium-sized Enterprises and Regional Development.

Note: Values in US dollars, converted according to the Banco Nación retail dollar seller, 16/12/2014.

of women in the board of directors and in senior management with the level and period of indebtedness, which is contrary to what was observed by Mínguez-Vera and López-Martínez (2010). The absence of significant results can be due to a weak relation between variables, which is not detectable given the reduced sample size.

There is a tendency in the companies audited by women to have a higher ratio of total liabilities on the total net worth of their assets. This result is consistent with the observations of Ittonen et al. (2013), as the precision and efficiency of female auditors would have an impact in a higher confidence generated by the financial reports, reducing informative asymmetries, and thus associating with greater indebtedness.

It is worth mentioning that in the case of companies that issue negotiable obligations, the conclusions of this study do not directly cover the entire universe of the SMEs, where bank financing prevails. Similarly, the reduced size of the population being studied prevents the realization of multivariate analyses of the problem. The potential existing distortions in the accounting information analyzed, particularly regarding the values of the Net Worth of the companies, ${ }^{8}$ also represent a limitation of this study.

The originality of this work lies in at least three factors. Firstly, aspects of corporate governance and gender in small and medium sized enterprises are studied, when most of other works in this subject matter have focused on large companies. Secondly, a contribution is done regarding emerging countries, for which there are very few previous empirical studies. Lastly, a unique database was created using the financial and CG information of issuer SMEs. This helps outline, as a future line of research, the advantages and disadvantages of a greater regulatory requirement for the information related to the $\mathrm{CG}$ for this type of companies.

\section{Annex.}

Table 6 presents the levels of maximum sales per year (in US dollars) to fall into the category of "Small and Medium-sized Enterprise", established by the Secretariat for Small and Mediumsized Enterprises and Regional Development (Secretaría de la Pequeña y Mediana Empresa y Desarrollo Regional) in its Resolution 50/13.

\footnotetext{
8 The financial statements presented in Argentina are not revised for inflation. The accumulated inflation during the period of June 2011-May 2013 in Argentina is around 118\% (Source: Consumer Price Index, Statistics Institute of San Luis). The International Accounting Standard No. 29, applicable to the accounting information of hyperinflationary economies, poses, among other aspects, the need to revise the data for inflation if the accrued inflation rate of three years is close or higher than $100 \%$.
} 
Table 7

List of companies analyzed.

\begin{tabular}{|c|c|c|c|c|}
\hline Issuing & Sector & Prospect date & Sales $2013^{\mathrm{a}}$ & $\begin{array}{l}\text { Age before the } \\
\text { prospect date }\end{array}$ \\
\hline Cosas Nuestras SA & Commerce & January-11 & $25,401,070.05$ & 8.8 \\
\hline Ersa Urbano SA & Services & June-11 & $117,267,752.15$ & 10.4 \\
\hline Álvarez Hermanos SA & Agricultural & July-11 & $8,884,689.78$ & 50.8 \\
\hline Rizobacter Argentina SA & Agricultural & September-11 & $108,959,698.55$ & 28.0 \\
\hline Edisur SA & Construction & October-11 & $13,162,900.54$ & 7.5 \\
\hline Construir SA & Construction & May-12 & $14,891,713.19$ & 20.8 \\
\hline Ovoprot SA & Industry and mining & September-11 & $32,159,159.22$ & 10.6 \\
\hline Asahi Motors SA & Commerce & August-12 & $47,482,719.41$ & 15.7 \\
\hline Percomin SA & Commerce & September-11 & $12,215,918.96$ & 55.2 \\
\hline Ultracongelados Rosario SA & Industry and mining & September-11 & $10,326,277.44$ & 13.4 \\
\hline Gama SA clase A & Services & November-12 & $28,101,869.76$ & 1.0 \\
\hline Euro SA & Agricultural & December-12 & $17,794,658.66$ & 13.2 \\
\hline Ebucar SA & Services & January-13 & $3,809,258.17$ & 9.9 \\
\hline Centro Card SA & Services & March-13 & $13,372,319.74$ & 10.6 \\
\hline AMS Food International SA & Industry and mining & April-13 & $952,967.08$ & 12.0 \\
\hline Compañía Integral de Alimentos & Services & December-12 & $21,033,020.54$ & 33.1 \\
\hline Big Bloom SA & Commerce & June-13 & $44,730,431.50$ & 12.0 \\
\hline Meranol SA & Industry and mining & September-11 & $51,636,784.74$ & 51.6 \\
\hline Regional Trade SA & Commerce & June-13 & $28,705,700.84$ & 23.6 \\
\hline Ingacot SA & Agricultural & July-13 & $1,864,228.97$ & 11.9 \\
\hline San Juan Inversiones & Services & December-12 & $514,907.44$ & 8.5 \\
\hline BF Argentina SA & Services & August-13 & $11,155,643.05$ & 15.3 \\
\hline Decreditos SA & Services & September-13 & $18,753,485.82$ & 13.1 \\
\hline Indo SA & Services & December-12 & $3,430,718.51$ & 8.0 \\
\hline Alianza Semillas SA & Industry and mining & October-13 & $21,149,003.84$ & 6.5 \\
\hline InsuAgro SA & Industry and mining & April-13 & $32,936,313.33$ & 11.0 \\
\hline Empresur SA & Services & November-13 & $10,428,811.66$ & 8.6 \\
\hline Savant Pharm SA & Industry and mining & July-13 & $49,095,762.76$ & 19.5 \\
\hline South Management SA & Services & July-13 & $148,419,747.31$ & 24.1 \\
\hline Actual SA & Services & December-13 & $10,574,173.57$ & 23.2 \\
\hline Plásticos DISE SA & Industry and mining & June-13 & $16,067,820.93$ & 24.5 \\
\hline Trantor SA & Commerce & January-14 & $2,651,186.78$ & 14.8 \\
\hline Tinuviel SA & Services & April-14 & $2,867,960.86$ & 9.3 \\
\hline
\end{tabular}

Source: Own elaboration based on information from financial statements and issuance prospects.

a Note: Values in US dollars, converted according to average of the Banco Nación retail dollar seller for 2013 $(\$ / \mathrm{U} \$=5.467)$.

\section{References}

Abor, J., \& Adjasi, C. K. (2007). Corporate governance and the small and medium enterprises sector: Theory and implications. Corporate Governance, 7(2), 111-122. http://dx.doi.org/10.1108/14720700710739769

Agrestri, A. (2002). Categorical data analysis (2nd ed.). Wiley. http://dx.doi.org/10.1007/978-3-642-04898-2_161

Arosa, B., Iturralde, T., \& Maseda, A. (2013). The board structure and firm performance in SMEs: Evidence form Spain. Investigaciones Europeas de Dirección y Economía de la Empresa, 19, $127-135$. http://dx.doi.org/10.1016/j.iedee.2012.12.003

Banco Mundial. (2010). Resultados de la World Enterprise Surveys.. Available from: http://espanol.enterprisesurveys.org/ data/exploreeconomies/2010/argentina\#gender Accessed 07.07.14

Braga Alves, M., \& Shastri, K. (2011). Corporate governance, valuation, and performance: Evidence from a voluntary market reform in Brazil. Financial Management, 40, 139-157. http://dx.doi.org/10.1111/j.1755-053X.2010.01137.x 
Brunninge, O., Nordqvist, M., \& Wiklund, J. (2007). Corporate governance and strategic change in SMEs: The effects of ownership, board composition and top management teams. Small Business Economics, 29, $295-308$. http://dx.doi.org/10.1007/s11187-006-9021-2

Campos, C., Newell, R., \& Wilson, G. (2002). Corporate governance develops in emerging markets: Shareholders in emerging markets show they're willing to pay a premium for good governance standards. McKinsey on Finance, (Winter), 15-18.

Carter, S., Shaw, E., Lam, W., \& Wilson, F. (2007). Gender, entrepreneurship, and bank lending: The criteria and processes used by bank loan officers in assessing applications. Entrepreneurship Theory and Practice, 31(3), 427-444. http://dx.doi.org/10.1111/j.1540-6520.2007.00181.x

Casal, A. (2010). Gobierno Corporativo. Dirección, Administración y Control de Organizaciones en Forma Ética. Buenos Aires: Ed. Errepar.

Constantinidis, C., Cornet, A., \& Asandei, S. (2006). Financing of women-owned ventures: The impact of gender and other owner- and firm-related variables. Venture Capital, 8(2), 133-157. http://dx.doi.org/10.1080/13691060600572557

Daily, C., Certo, T., \& Dalton, D. (1999). A decade of corporate women: Some progress in the boardroom, none in the executive suit. Strategic Management Journal, 20(1), 93-99.

Dasilas, A., \& Papasyriopoulos, N. (2015). Corporate governance, credit ratings and the capital structure of Greek SME and large listed firms. Small Business Economics, 45, 215-244. http://dx.doi.org/10.1007/s11187-015-9648-y

Farrell, K. A., \& Hersch, P. L. (2005). Additions to corporate boards: The effect of gender. Journal of Corporate Finance, 11, 85-106. http://dx.doi.org/10.1016/j.jcorpfin.2003.12.001

Francoeur, C., Labelle, R., \& Sinclair-Desgagné, B. (2008). Gender diversity in corporate governance and top management. Journal of Business Ethics, 81, 83-95. http://dx.doi.org/10.1007/s10551-007-9482-5

Garay, U., \& González, M. (2008). Corporate governance and firm value: The case of Venezuela. Corporate Governance: An International Review, 10, 194-209. http://dx.doi.org/10.1111/j.1467-8683.2008.00680.x

Grant Thornton International, International Business Report. Available from: http://www.gtar.com.ar/comunicados2015. html Accessed 11.02.16

Instituto Argentino de Mercado de Capitales. (2013). Informe Annual.. Available from: http://www.iamc.com.ar/ resultadosCompleto/busqueda/informeanuario/ Accessed 01.10.20

Ittonen, K., Vähämaa, E., \& Vähämaa, S. (2013). Female auditors and accruals quality. Accounting Horizons, 27, $205-228$. http://dx.doi.org/10.2308/acch-50400

Jensen, M., \& Meckling, W. (1976). Theory of the firm: Managerial behavior, agency costs, and ownership structure. Journal of Financial Economics, 3, 305-360. http://dx.doi.org/10.1016/0304-405X(76)90026-X

Johnsen, G., \& McMahon, R. (2005). Owner-manager gender, financial performance and business growth amongst SMEs from Australia's Business Longitudinal Survey. International Small Business Journal, 23(2), $115-142$. http://dx.doi.org/10.1177/0266242605050509

Kang, E., Ding, D. K., \& Charoenwong, C. (2010). Investor reaction to women directors. Journal of Business Research, 63, 888-894. http://dx.doi.org/10.1016/j.jbusres.2009.06.008

Klapper, F., \& Love, I. (2004). Corporate governance, investor protection, and performance in emerging markets. Journal of Corporate Finance, 10, 703-728. http://dx.doi.org/10.1016/S0929-1199(03)00046-4

López Vergara, M., Gómez-Betancourt, G., \& Betancourt Ramírez, J. (2011). Factores que influyen en la participación dela mujer en cargos directivos y órganos de gobierno de la empresa familiar colombiana. Cuadernos de Administración, 24(42), 253-274.

Mínguez-Vera, A., \& López-Martínez, R. (2010). Female directors and SMES: An empirical analysis. Journal of Global Strategic Management, 8, 34-46. http://dx.doi.org/10.20460/JGSM.2010415823

O'Donnell, E., \& Johnson, E. N. (2001). The effects of auditor gender and task complexity on information processing efficiency. International Journal of Auditing, 5, 91-105. http://dx.doi.org/10.1111/j.1099-1123.2001.00328.x

Santolíquido, D., Briozzo, A., \& Albanese, D. (2014). Gobierno corporativo, rentabilidad y financiamiento en Pymes. In XXXIV Jornadas de la Sociedad de Docentes en Administración Financiera.

Young, M. N., Peng, M. W., Ahlstrom, D., Bruton, G. D., \& Jiang, Y. (2008). Corporate governance in emerging economies. Journal of Management Studies, 45, 196-220. http://dx.doi.org/10.1111/j.1467-6486.2007.00752.x 